\title{
SPATIAL DIVERSIFICATION OF ENERGY CROPS IN POLISH AGRICULTURE: A STUDY OF PLANTATION CONCENTRATION BASED ON LOCAL INDICATORS OF SPATIAL ASSOCIATION (LISA)
}

\author{
AnNa KoŁOdZIEJCZAK ${ }^{1}$, Roman RudnickI ${ }^{2}$ \\ ${ }^{1}$ Institute of Socio-Economic Geography and Spatial Management, Adam Mickiewicz University, Poznań, \\ Poland \\ ${ }^{2}$ Department of Spatial Management and Tourism, Nicolaus Copernicus University, Torun, Poland
}

Manuscript received: October 5, 2016

Revised version: February 13, 2017

\begin{abstract}
KoŁodziejCZAK A., Rudnicki R., 2017. Spatial diversification of energy crops in Polish agriculture: A study of plantation concentration based on local indicators of spatial association (LISA). Quaestiones Geographicae 36(2), Bogucki Wydawnictwo Naukowe, Poznań, pp. 49-56, 1 table, 2 figs.

AвSTRACT: The paper deals with the spatial diversification of energy crops and their concentration in the Polish agriculture. The analysis of changes in territorial patterns regarding those plantations involves natural factors, effects of urbanisation, and the level of absorption of European Union funds. The concentration of plantations is presented by means of local spatial correlations of energy crops; for the purposes of this research, local Moran's statistic (Ii) has also been employed.
\end{abstract}

KEY WORDS: energy crops, concentration, autocorrelation, Poland

Anna Kołodziejczak, Institute of Socio-Economic Geography and Spatial Management, Adam Mickiewicz University, ul. Bogumita Krygowskiego 10, 61-680 Poznań, Poland; e-mail: aniaka@amu.edu.pl

Roman Rudnicki, Department of Spatial Management and Tourism, Nicolaus Copernicus University, ul. Lwowska 1, 87-100

Toruń, Poland; e-mail: rudnickir@umk.pl

\section{Introduction}

A growing cost of energy is one of the factors which may influence the direction of agricultural development in the future. The process is related to the growing costs of the extraction of energy-rich resources, which leads to a rise in the cost of food production. In order to reduce the costs of raw materials, the area of energy-crop plantations is likely to expand; thus, the role of agriculture in the production of energy from renewable resources will become more appreciable.
Polish agriculture is considered in the EU to be among those with the highest potential for biomass production for energy purposes. By 2030, energy crops are expected to reach 25 million ha in the EU (Wiesenthal et al. 2006). The document Energy policy of Poland until 2025 assumes that the use of biomass will still be the basic form of development of renewable energy production. In accordance with the Regulation of the Minister of Economy and Labour the amount of agricultural biomass was to have reached $5.4 \%$ of the total biomass used for energy purposes in 2008 and was 
to be larger by $10 \%$ year to year (Journal of Laws, 2004, No. 267, item 2656). Agriculture must reconcile food and fodder production, which should take place on the best soils, with the production of crops for energy provision, which is perforce on soils of limited agrarian use. The European and Polish economic policies presume that in a few years to come the area of energy-crop plantations will grow, which will be necessary to meet the targets for renewable energy production. An increase in their area may, but not necessarily, affect ecosystems adversely. Therefore, it is highly essential to diversify energy crops. Their plantations should be located in the vicinity of processing plants in order to reduce costs of biomass transportation. This may lead to a locally increased share of energy crops in the plantation structure, which will make energy crops a new - and more and more significant - element of agricultural production. Farmers make decisions about production taking into account a range of conditions related to the climate, soil quality, structure of agricultural holdings, a production strategy, production profitability, and subsidies.

The involvement of agricultural resources in renewable energy production agrees with the concept of the multifunctional development of rural areas discussed in the 2009 governmental document Rural development outline (Polish: Zarys kierunków rozwoju obszarów wiejskich). It assumes that in the case of agriculture production does not merely involve food. Growth directions for rural areas include also their use for biomass production, which should positively affect the level of agricultural diversification.

Like other countries under the Single Area Payment Scheme, Poland was embraced by the European aid programme for energy crops planted for renewable energy and biofuel. The payments started in 2005 with 213.40 zlotys per ha (only for osier and Japanese rose); the subsequent years saw, on the one hand, the list of subsidised species extended (e.g. rye, rapeseed, sugar beetroots) and, on the other hand, a decrease in the amount of subsidies (e.g. 190.33 zlotys per ha in 2009). Due to amended EU regulations, the payments ceased in 2010; in all, 2.6 thous. Polish agricultural holdings received financial aid for energy crops to the total amount of 30.1 million zlotys (Rudnicki 2014a).
The document Presidency conclusions of the European Council held in Brussels on 8-9 March 2007 includes targets for a reduction of greenhouse gases by 2020 (by 20\% as compared with the 1990 level), discusses the necessity for limiting energy consumption by $20 \%$ (against forecasts for 2020), and defines the share of renewable energy (20\%) in total energy consumption in Europe. This marked the start of the withdrawal of subsidies for energy-crop plantations. A new directive on the promotion of renewable energy sources came into effect in 2009, which imposed 'environmental sustainability criteria' for biofuels and biomass and, thus, limited the chances of their further development (Directive of the European Parliament 2009).

In consequence of those formal and legal changes, since 2010 energy crops in Poland have been excluded from the Single Area Payment Scheme, and the European financial aid for those plantations constitutes only a supplementary allowance dependent on the area covered by the Scheme. This kind of support was available to farmers who grew energy crops and had already signed contracts for the supply of energy sources, or who used and processed plants for energy purposes on their agricultural holdings. The assumption was that the policy promoting the development of green energy should, to a larger extent, account for regional - or even local conditions and needs. The cultivation of energy crops used as energy sources is, in fact, dependent on both natural factors and organisational arrangements, as farmers who grow these energy sources must meet the sustainable growth criteria (since 2010). A major limitation is a set of economic factors, because the production must be located, first and foremost, on poorer soils which give a smaller harvest and, as a result, raise the costs of production.

The aim of this paper is to present a geographical and agricultural study of the diversification of energy crops, those crops being a new element in the spatial structure of Polish agriculture. The basis of the analysis was the territorial pattern of the share of energy crops in the total area of agricultural holdings and their territorial concentration, i.e. local spatial correlations in Poland in the years 2007-2010, established by means of the local indicators of spatial association (LISA). 


\section{Materials and methods}

The first estimates of the area of energy-crop plantations in Poland employed in this research come from 2007, giving a total of 180 thous. ha, including as many as 173 thous. ha occupied by traditional crops (cereals, rapeseed) used for energy purposes (Celińska 2009). According to the 2010 Agricultural Census, one of the information sources used in this study, this area amounts to 154 thous. ha.

Poviats, i.e. 314 poviat offices of the Agency for Restructuring and Modernisation of Agriculture, which is the paying agent of European aid for Polish farmers, became the basic units in the analysis (for the characteristics of the organisational structure of the Agency with its division into regional and poviat branch offices, see Rudnicki 2009: 6-8).

In order to arrive at a more profound assessment of the spatial diversification of energy crops, the analysis involved three kinds of determinants:

- natural factors, defined on the basis of the index of quality of the agricultural production area established by the Institute of Soil Science and Plant Cultivation in Puławy and taking into account the application criteria for the 2007-2013 Rural Development Programme Aid to Farmers in Less Favoured Areas (LFA); the following categorisation applied: below 52 points - areas with unfavourable conditions; 52-72 points - areas with moderate conditions; and above 72 points (which precluded subsidies for LFA) - areas with favourable conditions;

- urbanisation, defined on the basis of a simplified division of poviats into poorly urbanised (country districts including small towns and rural areas) and highly urbanised (townships including large towns and cities only); and

- the amount of European subsidies, defined on the basis of data from the Agency for Restructuring and Modernisation of Agriculture and of the calculation of the total amount of subsidies received by agricultural holdings within the framework of the Common Agricultural Policy (90.5 billion zlotys in 2002-2010; cf. Rudnicki 2014 a, b) per 1 ha of agricultural land with good agricultural conditions; then the results were standardised
(Racine, Raymond 1977), i.e. presented in the form of a composite index showing poor (below $0.50 \delta)$, moderate $(+/-0.50 \delta)$ and high absorption of the CAP funds (above $0.50 \delta$ ), according to the following formula (Runge 2007):

$$
W_{s}=\frac{\sum_{j=1}^{p} y_{i j}}{p},
$$

where:

$W_{s}$ - the composite index,

$p$ - number of characteristics $j-1,2, \ldots, p$,

$y_{i j}$ - standardised value of the $j^{\text {th }}$ characteristic of the $i^{\text {th }}$-area.

The study of the local correlations between the analysed variables was carried out using a correlation indicator which accounts for the spatial location of the units, i.e. spatial autocorrelation. Spatial correlation is connected with the presence of spatial associations (Anselin 1988), which are defined as an influence of a process or a phenomenon at one point/ several points in a particular area on the course of that process or phenomenon at another point. According to Tobler's First Law of Geography (1970), such an influence wanes proportionally to the increase in the distance between points. The result of spatial associations is the correlation between the values of one variable measured at different points. As Bivand (1980) demonstrates, autocorrelation applies when the occurrence of one phenomenon in a particular spatial unit causes an increase or a decrease in the likelihood of the occurrence of that phenomenon in the neighbouring units. Spatial autocorrelation defines the association level for a particular spatial unit with the value of the same variable in another unit (location). For the establishment of local spatial associations related to a particular phenomenon, global $(I)$ and local Moran's statistics (Ii) were used. The description and use of those statistical methods can be found, for example, in Cliff and Ord (1973), Anselin (1995), or Kossowski and Perdał (2014).

Global Moran's statistic $(I)$ is for the definition of the general similarity of spatial units in terms of a given phenomenon. Positive and significant values achieved here mean that spatial autocorrelation occurs, i.e. the units studied are similar to each other within a particular distance. On the other hand, negative values indicate the absence 
of spatial correlation and show that the units are different from each other. However, to identify the departures from the global pattern of spatial correlation, local Moran's statistic should be applied. Here the calculations are made for every spatial unit, making it possible to determine how probable the similarity of a region to the neighbouring regions is and to check if a region is surrounded by regions characterised by high or low values of a given variable. The use of the local statistics helps to discover local spatial correlations. The analysis of local spatial correlations was conducted by means of one of the LISA methods worked out by Anselin (1995), viz. local Moran's statistic (Ii), which is suitable to check if a given spatial unit is in the neighbourhood of units with similar or different values of the variable under study. Local Moran's statistic (Ii) has the following formula:

$$
I_{i}=z_{i} \sum_{j=1}^{n} w_{i j} z_{j}
$$

where:

$w_{i j-}$ elements of the weight matrix $(\mathbf{W})$;

$z_{i^{\prime}} z_{j}$ - departures from the average, i.e. elements

of the previously described $\mathbf{z}$ vector.

Local Moran's statistic has a more or less normal layout. The units with statistically significant Ii values are used to find agglomeration effects in the form of clusters with low or high values of a given variable. There are two kinds of clusters: high-high $(\mathrm{HH})$ - clusters of units with high values of a variable surrounded by units with high values of that variable, and low-low (LL) - clusters of units with its low values surrounded by similar units. There are also two kinds of clusters characterised by departures from the standard: low-high (LH) and high-low (HL). The final result of a LISA analysis is a set of maps of typical and non-standard clusters.

The analysis of local spatial correlations was conducted for poviats and covered the period of 2007-2010. A detailed characterisation of spatial

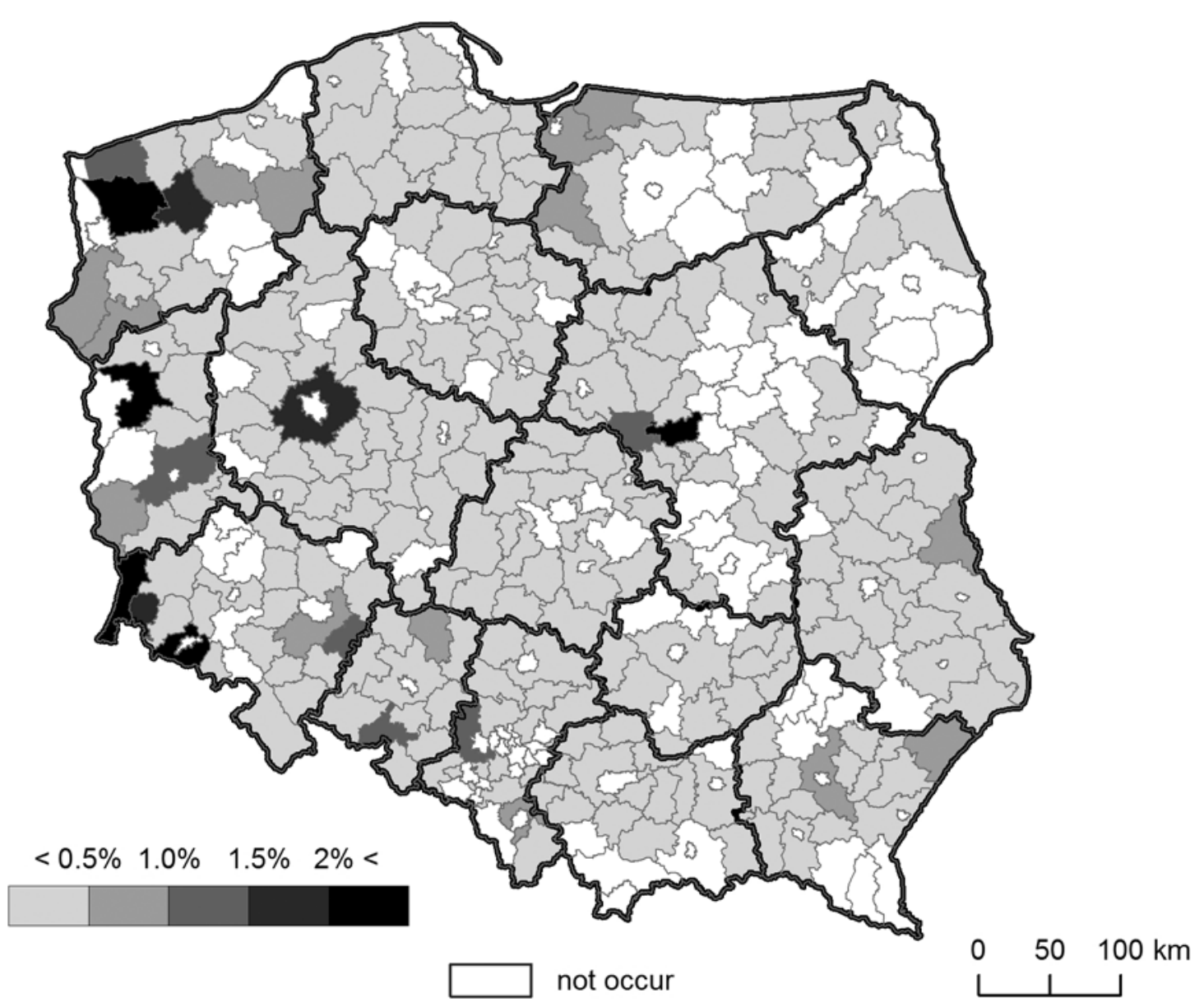

Fig. 1. Share of energy-crop plantations in the total area of agricultural holdings in poviats in Poland in 2010. Source: own study on the basis of the 2010 Agricultural Census. 
structures and correlations was performed by means of the LISA method, which used the weight for five nearest neighbours. The intensity/ volume ratio was measured on the basis of the area of energy crops. The calculations were made using the GeoDa computer programme.

\section{Results and discussion}

Energy crops have different concentrations in particular Polish regions. In 2010 the number of agricultural holdings growing energy crops amounted to 92 thous., or $4.1 \%$ of their total number (from $1.8 \%$ in Lower Silesia to $6.4 \%$ in
Subcarpathia). Energy crops were cultivated on 154 thous. ha, which included:

- 17.1 thous. ha of arable land, with 14.6 thous. ha occupied by annual plantations (domination of rapeseed and agrimony - 37\%) and 2.5 thous. ha taken by perennial plantations (domination of elephant grass - 78\%); and

- 135.3 thous. ha of fast-growing tree and bush plantations in forests and woodland (domination of osier - 70\%).

On average, energy-crop plantations in Poland amounted to $0.85 \%$ of the total area of agricultural holdings, from $0.35 \%$ in Podlasie to $2.63 \%$ in Kujavia-Pomerania (the spatial distribution with a breakdown into poviats is presented in Fig. 1).

Table 1. Energy crops on Polish agricultural holdings in 2010 - selected parameters.

\begin{tabular}{|c|c|c|c|c|c|c|c|}
\hline \multirow{3}{*}{\multicolumn{2}{|c|}{ Regions }} & \multicolumn{4}{|c|}{ Energy crops - total } & \multirow{2}{*}{\multicolumn{2}{|c|}{$\begin{array}{l}\text { Including area of energy-crop } \\
\text { plantations on arable land }\end{array}$}} \\
\hline & & \multicolumn{2}{|c|}{ Area } & \multicolumn{2}{|c|}{$\begin{array}{c}\text { Number of agricultural } \\
\text { holdings }\end{array}$} & & \\
\hline & & thous. (ha) & $\begin{array}{l}\% \text { of total area } \\
\text { of farms }\end{array}$ & thous. & $\begin{array}{l}\% \text { of total num- } \\
\text { ber of farms }\end{array}$ & $\begin{array}{l}\% \text { of energy-crop } \\
\text { acreage }\end{array}$ & $\begin{array}{l}\% \text { of total area } \\
\text { of plantations }\end{array}$ \\
\hline \multicolumn{2}{|c|}{ Lower Silesia } & 6.0 & 0.53 & 1.9 & 1.8 & 43.1 & 0.36 \\
\hline \multicolumn{2}{|c|}{ Kujavia-Pomerania } & 33.0 & 2.63 & 3.8 & 4.3 & 0.3 & 0.01 \\
\hline \multicolumn{2}{|c|}{ Lublin } & 9.1 & 0.55 & 10.1 & 3.9 & 5.8 & 0.05 \\
\hline \multicolumn{2}{|l|}{ Lubuska Land } & 10.7 & 2.04 & 1.2 & 2.7 & 11.1 & 0.41 \\
\hline \multicolumn{2}{|l|}{ Łódź } & 6.8 & 0.58 & 6.9 & 4.1 & 3.4 & 0.03 \\
\hline \multicolumn{2}{|l|}{ Małopolska } & 6.8 & 0.81 & 11.0 & 3.9 & 1.9 & 0.04 \\
\hline \multicolumn{2}{|l|}{ Mazovia } & 19.3 & 0.85 & 12.9 & 4.7 & 11.6 & 0.19 \\
\hline \multicolumn{2}{|l|}{ Opole } & 2.7 & 0.49 & 1.3 & 2.8 & 41.1 & 0.24 \\
\hline \multicolumn{2}{|l|}{ Subcarpathia } & 13.8 & 1.62 & 17.0 & 6.5 & 4.7 & 0.21 \\
\hline \multicolumn{2}{|l|}{ Podlasie } & 4.5 & 0.35 & 2.6 & 2.5 & 0.4 & 0.00 \\
\hline \multicolumn{2}{|l|}{ Pomerania } & 4.6 & 0.48 & 1.6 & 2.7 & 3.7 & 0.03 \\
\hline \multicolumn{2}{|c|}{ Silesia } & 4.5 & 0.86 & 5.5 & 3.6 & 12.9 & 0.22 \\
\hline \multicolumn{2}{|c|}{ Świętokrzyska Land } & 6.0 & 0.90 & 7.9 & 5.5 & 3.2 & 0.06 \\
\hline \multicolumn{2}{|c|}{ Warmia-Mazuria } & 9.6 & 0.75 & 3.3 & 4.9 & 12.9 & 0.20 \\
\hline \multicolumn{2}{|l|}{ Wielkopolska } & 10.1 & 0.52 & 4.9 & 3.0 & 25.8 & 0.18 \\
\hline \multicolumn{2}{|l|}{ West Pomerania } & 6.5 & 0.58 & 1.2 & 2.4 & 54.6 & 0.52 \\
\hline \multicolumn{2}{|l|}{ Poland } & 154.1 & 0.85 & 92.8 & 4.1 & 11.1 & 0.16 \\
\hline \multicolumn{8}{|c|}{ Including determinants: } \\
\hline \multirow[t]{3}{*}{ Natural factors } & 1 & 12.0 & 0.80 & 8.4 & 4.0 & 1.1 & 0.02 \\
\hline & 2 & 112.9 & 0.95 & 56.8 & 4.1 & 10.0 & 0.17 \\
\hline & 3 & 29.2 & 0.63 & 27.6 & 4.1 & 19.5 & 0.18 \\
\hline \multirow[t]{2}{*}{ Urbanisation } & 1 & 150.9 & 0.86 & 91.4 & 4.1 & 10.3 & 0.15 \\
\hline & 2 & 3.2 & 0.67 & 1.4 & 1.9 & 49.7 & 1.33 \\
\hline \multirow[t]{3}{*}{ CAP aid } & 1 & 24.0 & 0.99 & 30.7 & 4.5 & 10.7 & 0.23 \\
\hline & 2 & 57.1 & 0.65 & 43.1 & 3.9 & 16.7 & 0.19 \\
\hline & 3 & 73.0 & 1.06 & 19.0 & 3.8 & 6.9 & 0.12 \\
\hline
\end{tabular}

Natural factors: 1 - areas with unfavourable conditions; 2 - areas with moderate conditions; 3 - areas with favourable conditions; Urbanisation: 1 - poorly urbanised areas; 2 - moderately urbanised areas; CAP aid: 1 - low level; 2 moderate level; 3 - high level.

Source: own study on the basis of Central Statistical Office data - results of the 2010 Agricultural Census, and the 2004-2010 data of the Agency for Restructuring and Modernisation of Agriculture. 
The energy crops cultivated on arable land constituted $11.1 \%$ of all energy-crop plantations (from under $1 \%$ in Kujavia-Pomerania and Podlasie to almost 55\% in West Pomerania), and their share in the total area of all plantations equalled $0.16 \%$ (the lowest share being in Podlasie and the highest $-0.52 \%$ - in West Pomerania; cf. Table 1 ).

The analysis showed that the spatial diversification of energy crops was determined by natural conditions (mostly the quality of farmland) and man-made conditions related to urbanisation and the absorption of EU funds.

The influence of the natural environment is demonstrated by differences between areas with unfavourable and favourable natural conditions in terms of the share of energy crops in the total area of agricultural holdings $(0.8 \%$ and $0.63 \%$, respectively) and, essentially, the share of energy crops cultivated on arable land $(1.1 \%$ and $19.5 \%$, respectively) as well as their share in the total area of agricultural acreage $(0.02 \%$ and $0.18 \%$, respectively). It turned out that despite the recommended cultivation of energy crops in areas with unfavourable natural conditions, in the case of arable land their relatively higher rank applies to those poviats which fall into the category of areas with favourable conditions. It refers to large areas of plantations growing corn and rapeseed for energy purposes (9.9 thous. ha in total), mostly in areas with moderate and favourable natural conditions.

The spatial pattern of energy-crop plantations was also formed out of urbanisation processes. This fact is corroborated particularly by a large share of energy-crop plantations in towns, both in terms of the total area of the crops $(49.7 \%)$ and the total area of plantations $(1.33 \%)$.

The research demonstrated that the share of energy-crop plantations in the total area of agricultural holdings is the largest in poviats with a high level of absorption of CAP funds (1.06\%);

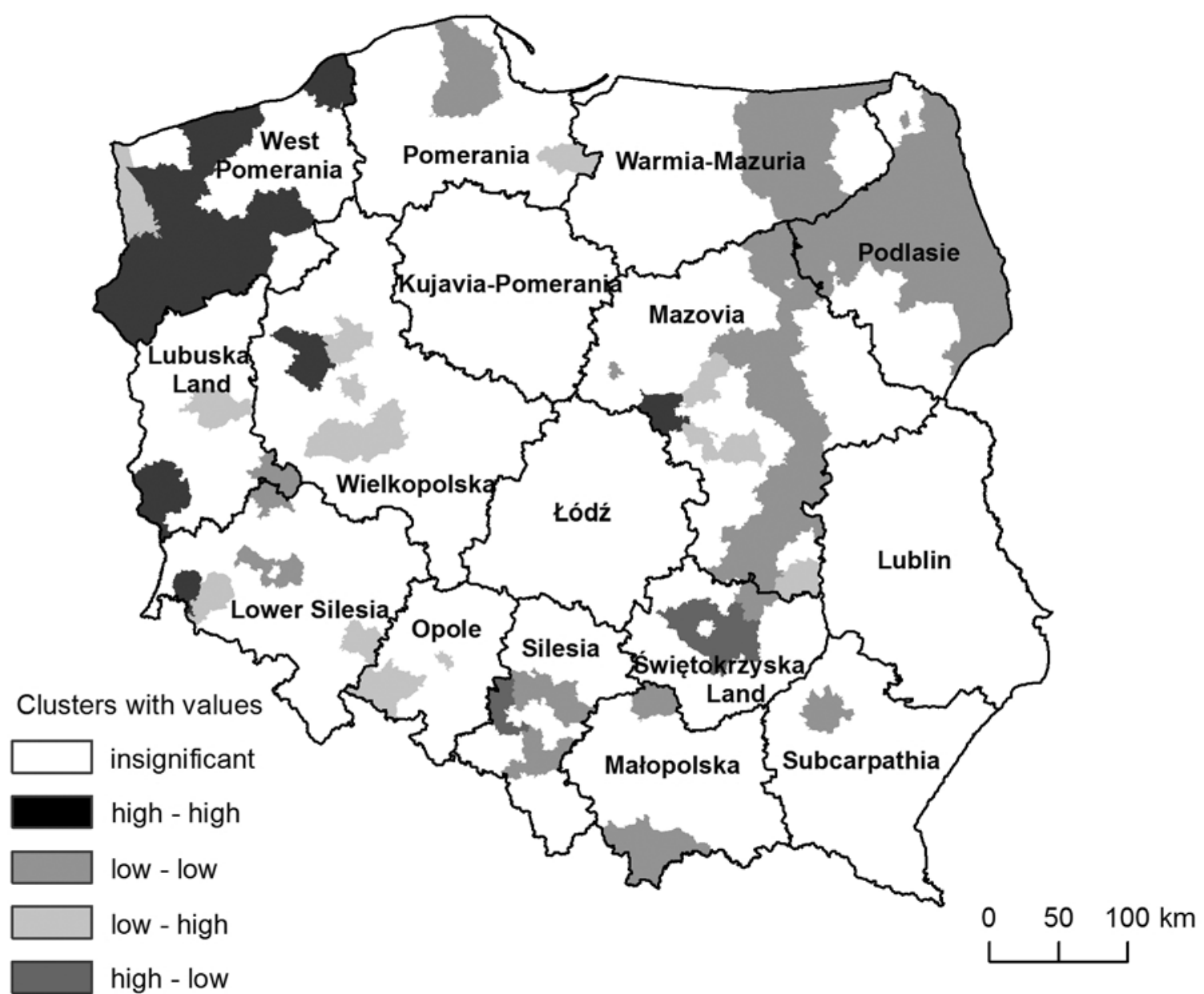

Fig. 2. Spatial correlations (LISA) in the volume of energy crops cultivated on arable land in Poland in 2010. Source: own compilation. 
however, when it comes to arable land, the share of energy-crop plantations in the total area of plantations is markedly smaller $-0.12 \%$ (cf. Table $1 ; 0.23 \%$ - poviats with a low absorption of CAP funds).

At this point it should be stressed that energy crops constitute a new element in the production structure of Polish agriculture developing since 2005 - the year when those crops were included in the Single Area Payment Scheme. Their spatial distribution, in spite of the patterns mentioned above, has not formed fully yet; it resembles a mosaic, and even poviats with similar conditions often differ considerably in terms of the parameters analysed, e.g. \% of the total area of farms.

The largest share of the studied plantations in the total area of energy-crop plantations was noted in the western part of the country: West Pomerania, Wielkopolska, Lower Silesia and Opole voivodeship. The local indicator of spatial association for the area of energy-crop plantations on arable land was statistically significant, at $a=0.05$. and amounted to 0.0765. The concentration of energy-crop plantations in 2010 is characterised by one outstanding $\mathrm{HH}$ cluster in northern Poland, on the border of West Pomerania and Lubuska Land. Such a high spatial correlation resulted from similar conditions in those areas, i.e. a large area of corn and rapeseed plantations and a high absorption level of CAP funds for energy sources. Smaller clusters occurred in Wielkopolska, Lower Silesia and the southern part of Lubuska Land (Fig. 2). Those clusters show a relatively moderate spatial cohesion. LL clusters are more prominent across the country and are more spatially cohesive than $\mathrm{HH}$ ones. The largest LL cluster was found in north-east Poland, corroborating the spatial correlation between a small share of energy-crop plantations in the total area of plantations. Such clusters, despite their poor spatial concentration, occur in Mazovia, while smaller ones can be found in Małopolska, Silesia, Lower Silesia and Wielkopolska. Additionally, the structure of those clusters includes so-called 'outliers'. They were noted in the Świętokrzyska Land clusters where the volume of energy crops was significantly higher than in the neighbouring units; as a result, they form HL outliers. The contrasting phenomenon was discovered in Mazovia, with LH outliers.
Even though energy crops were cultivated in Kujavia-Pomerania, Łódź and Lublin voivodeships, the poviats located there did not show any spatial correlations, i.e. there was no similarity between adjacent units.

\section{Conclusions}

Polish agriculture enters a new phase of development where the production of energy sources is as important as that of food. It will be essential to maintain the right proportions between crops dedicated for those two purposes, and in compliance with sustainable development principles in farming.

Subsidies to energy crops for farmers caused a reduction in the area of land set aside and fallow land, and in consequence protected many areas from the loss of their agrarian nature. The payments which were in effect until 2010 contributed to the enlargement in the area of energy-crop plantations (154 thous. ha), but farmers were not enthusiastic about developing this kind of production. However, the Polish commitment towards an increased biomass volume used for energy purposes requires an individual programme for the development of energy crops and the optimisation of their spatial distribution. This was demonstrated by an analysis of the share of energy crops in the total area of arable land, conducted by means of the local indicators of spatial association. The said method made it possible to distinguish areas (clusters) of poviats characterised by similar volumes of energy crops and pointed to the influence of neighbouring areas and to spatial correlations occurring between adjacent poviats. This research method facilitated an approach to the discussed problem from the perspective of a spatial analysis and was an invaluable addition to the study and corroboration of the results acquired by means of other statistical methods.

On the basis of forecasts of the consumption of renewable energy in the future, it can be predicted that the cultivation of energy crops will become a source of income for many people. It opens prospects for farmers whose unprofitable traditional crops force them to seek new sources of income. 


\section{Acknowledgements}

The authors would like to express their gratitude to the National Science Centre for providing funds for the research under the 2011/03/B/ HS4/04952 project.

\section{References}

Anselin L., 1988. Spatial econometrics: Methods and models. Kluwer, Dordrecht.

Anselin L., 1995. Local Indicators of Spatial Association LISA. Geographical Analysis 27: 93-115.

Bivand R., 1980. Autokorelacja przestrzenna a metody analizy statystycznej w geografii (Spatial autocorrelation and methods of statistical analysis in geography). In: Chojnicki Z. (ed.), Analiza regresji w geografii. PWN, Poznań: 23-38.

Celińska A., 2009. Charakterystyka różnych gatunków roślin energetycznych $\mathrm{w}$ aspekcie ich wykorzystania $\mathrm{w}$ energetyce zawodowej (Characteristics of various species of energy plants in terms of their use in the power industry). Polityka Energetyczna 1, 1/2: 59-72.

Cliff A.D., Ord J.K., 1973. Spatial autocorrelation. Pion, London.

Directive 2009/28/EC of the European Parliament and of the Council of 23 April 2009 on the promotion of the use of energy from renewable sources. Official Journal of the European Union 5.6.2009.

Kossowski T., Perdał R., 2014. Wykorzystanie metod ekonometrii przestrzennej do analizy procesów koncentracji w rolnictwie polskim (Use of spatial econometric methods to analyse concentration processes in Polish agriculture). In: Głębocki B. (ed.), Zróżnicowanie przestrzenne rolnictwa. GUS, Warszawa: 466-487.

Presidency conclusions of the European Council held in Brussels on 8-9 March 2007; 7224/1/07 REV 1http:// register.consilium.europa.eu/ doc/ srv?l=EN\&f=ST $\% 20$ 7224\%202007\%20REV\%201 (accessed February 2015).

Racine J.B., Reymond H. 1977. Analiza ilościowa w geografii (Quantitative analysis in geography). PWN, Warszawa.

Regulation of the Minister of Economy and Labour of 9 December 2004 on a detailed scope of obligations to procure electrical energy and thermal energy produced from renewable energy sources. Journal of Laws of 2004, No. 267, item 2656.

Rudnicki R., 2009. Renty strukturalne jako czynnik przemian agrarnych $i$ demograficznych $w$ rolnictwie polskim $w$ latach 2004-2006 (Structural pensions as a factor of agrarian and demographic changes in Polish agriculture in the years 2004-2006). Bogucki Wydawnictwo Naukowe, Poznań.

Rudnicki R., 2014a. Analiza absorpcji środków WPR i ich wpływu na zmiany strukturalne $\mathrm{w}$ rolnictwie polskim (Analysis of CAP funds and their effect on structural changes in Polish agriculture). In: Głębocki B. (ed.), Zróżnicowanie przestrzenne rolnictwa. GUS, Warszawa: 441-463.

Rudnicki R., 2014b. Changes in the land use structure of agricultural holdings in Poland in the light of comparative analysis of National Agricultural Censuses of 2002 and 2010. In: Kamińska W., Heffner K. (eds), Rural development and EU Cohesion Policy. Studia Regionalia KPZK PAN 39, Warszawa: 153-182.

Runge J., 2007. Metody badań w geografii społeczno-ekonomicznej - element metodologii, wybrane narzędzia badawcze (Research methods in socio-economic geography: Elements of methodology and selected research tools). Wydawnictwo Uniwersytetu Śląskiego, Katowice.

Tobler W., 1970. A computer movie simulating urban growth in the Detroit region. Economic Geography 46(2): 234-240.

Wiesenthal T., Wourelatou A., Petersen J.E., Taylor P., 2006. How much bioenergy can Europe produce without harming the environment? http://reports.eea.europa.eu/eea_report_2006_7/en (accessed February 2015).

Zarys kierunków rozwoju obszarów wiejskich (Outline of the development of rural areas), 2009. Ministry of Agriculture and Rural Development, Warszawa. 